\title{
Marie-Thérèse Ballin, Les "Historiettes" de Tallemant des Réaux. Manuscrit privé ou clandestin?
}

\section{Laura Rescia}

\section{Q OpenEdition}

1 Journals

\section{Edizione digitale}

URL: http://journals.openedition.org/studifrancesi/2136

DOI: 10.4000/studifrancesi.2136

ISSN: 2421-5856

\section{Editore}

Rosenberg \& Sellier

\section{Edizione cartacea}

Data di pubblicazione: 1 aprile 2014

Paginazione: 140

ISSN: 0039-2944

\section{Notizia bibliografica digitale}

Laura Rescia, "Marie-Thérèse Ballin, Les "Historiettes" de Tallemant des Réaux. Manuscrit privé ou clandestin? », Studi Francesi [Online], 172 (LVIII | I) | 2014, online dal 01 avril 2014, consultato il 18 septembre 2020. URL : http://journals.openedition.org/studifrancesi/2136 ; DOI : https://doi.org/ 10.4000/studifrancesi.2136

Questo documento è stato generato automaticamente il 18 settembre 2020.

\section{(c)}

Studi Francesi è distribuita con Licenza Creative Commons Attribuzione - Non commerciale - Non opere derivate 4.0 Internazionale. 


\title{
Marie-Thérèse Ballin, Les \\ "Historiettes" de Tallemant des Réaux. Manuscrit privé ou clandestin?
}

\author{
Laura Rescia
}

\section{NOTIZIA}

MARIE-THÉRĖSE BALLIN, Les "Historiettes" de Tallemant des Réaux. Manuscrit privé ou clandestin?, «Revue d'histoire littéraire de la France», vol. 113, 2013/12, pp. 259-277.

1 L'A. s'interroga sulla ricezione e diffusione dell'opera di Tallemant des Réaux che, notoriamente, fu pubblicata soltanto nel 1834: tale ritardo nella stampa sarebbe da addebitarsi unicamente ad una necessità di riservatezza, se non di segreto, necessaria per le «maldicenze» contenutevi, oppure è possibile ipotizzare una diffusione manoscritta, destinata ad un pubblico scelto e ristretto, o ancora una diffusione prevalentemente orale? La traiettoria compiuta delle Historiettes, indagata attraverso la storia dei manoscritti e delle stampe secentesche, le modalità di socializzazione coeve, le caratteristiche proprie del testo, nella sua frammentarietà, ibridità e allusività, conduce ad un'ipotesi suggestiva: la possibilità che questo testo, nato nella civiltà della conversazione, e che dall'oralità trae alcune sue peculiarità, sia ritornato e abbia circolato in forma manoscritta nello spazio sociale in cui fu concepito. 